Acta Horticulturae et Regiotecturae 2

Nitra, Slovaca Universitas Agriculturae Nitriae, 2016, pp. 41-48

\title{
GROWTH RESPONSE ASSESSMENT OF THE SYCAMORE MAPLE (ACER PSEUDOPLATANUS L.) IN CHANGED CITY ENVIRONMENT
}

\author{
Peter UHRIN*, Ján SUPUKA \\ Slovak University of Agriculture in Nitra, Slovak Republic
}

\begin{abstract}
Climate conditions in cities are constantly changing, creating a worsening environment for the growth of trees and performing their ecological functions. Qualitative evaluation of their responses to the often extreme climatic conditions and habitat for their growth is an important part of care for urban and historical greenery. This work deals with applying visual methods for the assessment of morphological characters, crown destructive manifestations and eco-physiological aspects of vitality through micromarker of quality of assimilation organs. Evaluation was carried out in two types of environment, in city of Nitra and an environmentally unloaded historical park in Nová Ves nad Žitavou. The research was conducted on six trees of species Acer pseudoplatanus L., through visual assessment and measuring the values of chlorophyll fluorescence-a. The measurement results were statistically evaluated and graphically interpreted.
\end{abstract}

Keywords: trees in city, evaluation, visual markers, chlorophyll fluorescence

Today, urban spaces represent a markedly changing environment with constantly worsening urban microclimate for plants growth and their development. Urban environment as opposite to the parks environment can be characterized by higher air temperatures (Quigley, 2004; Leuzinger, Vogt and Körner, 2010), lower degree of air humidity, which may lead to higher evapotranspiration demand on trees. High daytime temperatures can directly affect plants by tissue overheating, or indirectly through the water deficit, that may be caused by high evaporative losses (Slováková and Mistrík, 2007). Overheating hard surfaces (eg. asphalt, concrete, paved) or the soil profile may result in a reduction of water potential and overheating of the root system. Lack of water in the trees tissues or in assimilation organs during extreme temperatures may lead to the mortality of their parts (Střelcová and Kmet', 2003). Chronic effects of stress factors on plants such as environmental conditions can have negative impacts on their vitality.

Evaluation of trees vitality is quite difficult, because this ability of existence implies the development trends and genetic value. It is established indirectly, by interpretation of relevant marks and indicators that reflects the current structure or function deviation from the optimum or normal state. Interpretation of this phenomenon - how big reduction in vitality deviation was caused, or how impact on the vitality the resulting deviation will have - is quite difficult (Pejchal, 1997). The stress situation can be assessed at different levels of biological systems, by macroscopic evaluation characters, physiological or physiologicalbiochemical parameters. Bioindication of plants stress level is a complex process that requires a comprehensive view. Utilisation of physiological and biochemical parameters for the determination of early stress stages and characterization of plant response to environmental stress becomes very frequent in methodological and research practices (Kmet', DItmarová a Kurjak, 2009). Impact of stress and hence the adaptability of plants to changing environmental conditions is often assessed by measuring chlorophyll fluorescence, because it is an appropriate non-destructive method of assessing the quality of assimilation organs of trees. This method has been used in Works of several authors (Jasenka, 2011; Jasenka and Supuka, 2011; Supuka, Kmet' and Jasenka, 2010; and others). The evaluation results of measured fluorescence induction kinetics parameters provide a useful image of plants response to changing environmental conditions and therefore, to a certain extent, the picture of their adaptability to climate, hydrology, soil conditions and characteristics of the research area.

\section{Material and methods}

For research and evaluation, there were selected 6 plants of Acer pseudoplatanus L., of which three individuals were located in city Nitra on the Trieda Andreja Hlinku street and three individuals were on the comparative locality in the rural historical park in Nová Ves nad Žitavou. The average tree age was assessed to 50-70 years and their average height was around 10-14 m. Visual assessment and measurement of chlorophyll fluorescence on model woody plants was carried out at both locations in the same terms for Nitra and Nová Ves nad Žitavou. It was in both cases at the turn of June and July in the first measurement and in August 2015 in the second measurement. 


\section{Clima conditions characteristics}

Basic climate data for the area of Nitra were obtained from the Department of Biometeorology and Hydrology on Faculty of Horticulture and Landscape Engineering in the Slovak University of Agriculture in Nitra and from the Slovak Hydrometeorological Institute. For the model area of the historical park in Nova Ves nad Žitavou, there have been used data obtained from the standardized meteorological station at the nearby institutes of the Slovak Academy of Sciences in the Arboretum Mlyñany. Basic climatic data such as monthly maximum temperature, monthly minimum temperature, average monthly temperature and monthly rainfall were compared.

\section{General characteristics of the model areas}

The health assessment or vitality assessment of model trees was carried out in two types of locations with different degrees of environmental impact. As a locality with environmental preasure there has been selected Trieda Andreja Hlinku in Nitra. As a comparative and also environmentally unloaded area there has been selected the historical park in Nová Ves nad Žitavou.

\section{Trieda Andreja Hlinku}

Even despite the completion of the motorway bypass around the town of Nitra, this avenue heading to Bratislava remains one of the most heavily congested traffic communications in Nitra. In addition, lorries and public transport together with individual car transportation make major source of emission pressure on the trees. During transport hours (08:00-10:00 am, 12:00-14:00 pm and 15:00-17:00 pm) as many as 7,200 transport vehicles pass the avenue what was observed by us during the measurement. In this area there were assessed three trees which are located in $20 \mathrm{~m}$ wide linear vegetation belt, in the immediate distance from traffic roads isolating adjacent residential zone Chrenová I.

\section{The Park in Nová Ves nad Žitavou}

The park has an area of 6.6 hectares, it includes a historical manor house, currently used as an educational facility. The park is located to the east of the main road in the direction from Vráble to Zlaté Moravce. Three assessed individuals are distant from the main road, and hence the nearest potential source of environmental load, more than $75 \mathrm{~m}$ in the stand with poor canopy crowns. In qualitative terms, directly at the park there is no other source of environmental load.

\section{Measuring of chlorophyll fluorescence values}

Measurement of chlorophyll fluorescence was performed by the method in vivo in a live plant directly using the pulse fluorimeter FMS-2 (Fluorescence Monitoring System) from Hansatech company. The device measured basic parameters resulting from fluorescence induction kinetics of chlorophyll- $\alpha$. The measurement was carried out after 30 minutes of assimilation tissue adaptation of leaf area to leaf through the darkness clips Hansatech FMS / LC $7 \mathrm{~mm}$. During the measurement, the script was set up to the following characteristics and commands used: GAIN = 50; $M O D$ modulated frequency $=2 ; L O G=1 ; W A I T=10.0$; $F V / F M=2.5$ (period duration), 100 (saturation intensity of radiation), 0.8 (duration light pulses); WAIT $=20.0 ; A C T=$ 27 (actinic radiation); WAIT $=180.0 ;$ ФPS2 $=2.5$ (duration period), 100 (saturation intensity of the radiation), 0.8 (duration of light pulse); FO' (Far-red pulse duration) $=3.0$. Measuring of this procedure was the same for 10 developed and healthy leaves around the circumference of the tree at a height of $1.5 \mathrm{~m}$ to $2.5 \mathrm{~m}$ above ground. The result of each measurement was deposited into the control unit of the FMS-2 and then exported and evaluated using the software MODFLUOR-32.

\section{Visual evaluation method}

To assessing the quality of assimilation organs and faze of crown destruction there were selected these indicators: defoliation, mortification of crown and evaluation of leafs necrosion. Levels of defoliation were evaluated according to the methodology published by three autors: Pejchal (1995), Innes (1990), Supuka et al. (1991) with a point scale in the range from 0 (no loss of foliage) to 4 (total loss of foliage), same as the level of crown mortification (Pejchal, 1995) and the degree of leaves necrosis (Supuka et al., 1991).

For myco-destructive assessment and expressions of mechanical damage, there were assessed three indicators: mechanical impacts, cavities and fungi, and wounds callusing as a reaction to mechanical damage. Indicators were assessed in range from 0 to 4, where 0 represents the lowest range of destructive expression and range 4 the highest range. Mechanical damage was classified according to the type of pests by Hrubík and Tkáčová (2004). We may also include here trunk injury, roots injury, branches injury, but also frost cracks according to Bernatzky (1987), they were assessed according to a points evaluation system by Pejchal (1995) in the range from 0 (lowest level of influence) to 4 (highest influence). To each point values there were assigned percentage ratings defining the exact scope of the burst expression. The incidence of cavities and fungi as one of the biotic pests types by Hrubík and Tkáčová (2004) were assessed as an estimate as well as mechanically, by inserting a hard wire into the trunk or branch cavity, (Gáper, 1998; Gáper and Gáperová, 2009 ) and for failure accurate assessment of the extent cavities in the trunk there was made acoustic tomography of relevant trunk part. Callusing of wounds was evaluated by the callus width measuring and put in relation to the total surface of wounds area in $\mathrm{cm}^{2}$. Overall view of evaluated indicators is presented in Table 1.

Besides these characteristics, there were recorded dendrometric essential characteristics such as: tree height, crown width and girth of 1.3 meters above ground level. Basic values were measured with a laser rangefinder Leica DISTO model D-5.

Assessed plants were visually evaluated two times in approximately one month intervals and evaluated by the qualitative index by the following formula (Supuka et al., 1991):

$$
Q n=\frac{\sum A i \cdot x i+\sum B i \cdot x i+\sum C i \cdot x i}{\sum x i}
$$

where:

$\mathrm{Ai}-\mathrm{Ni}$ - type and character of evaluation feature $i$-th quality

Qn - quality index $n$-th plants

$x i \quad$ - the number of plants evaluated at a given locality 
Table $1 \quad$ Qualitative visual assessment indicators for tree evaluation

\begin{tabular}{|c|c|c|c|c|c|}
\hline \multirow{16}{*}{ 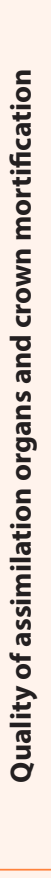 } & Indicator & Value & Range & Impact & Description \\
\hline & \multirow{5}{*}{$\begin{array}{l}\text { Defoliation } \\
\left(D_{i}\right)\end{array}$} & 0 & $0-10 \%$ & loss of foliage & - none to slight loss of foliage \\
\hline & & 1 & $11-25 \%$ & loss of foliage & - slight to moderate loss of foliage \\
\hline & & 2 & $26-60 \%$ & loss of foliage & - moderate to severe loss of foliage \\
\hline & & 3 & $61-90 \%$ & loss of foliage & - severe to complete loss of foliage \\
\hline & & 4 & $91-100 \%$ & loss of foliage & - complete loss of foliage \\
\hline & \multirow{5}{*}{$\begin{array}{l}\text { Crown } \\
\text { mortification } \\
\left(\mathrm{Cm}_{i}\right)\end{array}$} & 0 & $0-10 \%$ & wilt branches & - partial desiccation the lateral branches \\
\hline & & 1 & $11-25 \%$ & wilt branches & - mortification of tertiary branching \\
\hline & & 2 & $26-50 \%$ & wilt branches & - mortification of secondary branching \\
\hline & & 3 & $51-80 \%$ & wilt branches & - mortification of primary branching \\
\hline & & 4 & $81-100 \%$ & wilt branches & - mortification the main trunk in the whole profile \\
\hline & & 0 & $0-5 \%$ & leaf damage & - none to slight leaf damage as result of pests impact \\
\hline & & 1 & $5-25 \%$ & leaf damage & - slight to moderate leaf damage as result of pests impact \\
\hline & & 2 & $26-50 \%$ & leaf damage & - moderate to severe leaf damage as result of pests impact \\
\hline & & 3 & $51-75 \%$ & leaf damage & - severe to heavy leaf damage as result of pests impact \\
\hline & & 4 & $76-100 \%$ & leaf damage & - heavy to total leaf demage as result of pests impact \\
\hline \multirow{6}{*}{ 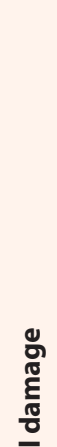 } & \multicolumn{5}{|c|}{ Abiotic pests: $a$ - wind, $b$ - snow, $c$ - frost, $d$ - lightning } \\
\hline & \multirow{5}{*}{$\begin{array}{l}\text { Mechanical } \\
\text { damage }\left(\boldsymbol{M} d_{i}\right)\end{array}$} & 0 & $0 \%$ & trunk injuries & - no damage \\
\hline & & 1 & $0-15 \%$ & trunk injuries & $\begin{array}{l}\text { - damage to } 15 \% \text { of the perimeter of the trunk, branches and } \\
\text { root swellings }\end{array}$ \\
\hline & & 2 & $16-30 \%$ & trunk injuries & $\begin{array}{l}\text { - damage from } 15 \% \text { to } 30 \% \text { of the perimeter of the trunk, } \\
\text { branches and root swellings }\end{array}$ \\
\hline & & 3 & $31-50 \%$ & trunk injuries & $\begin{array}{l}\text { - damage from } 31 \% \text { to } 50 \% \text { of the perimeter of the trunk, } \\
\text { branches and root swellings }\end{array}$ \\
\hline & & 4 & $51-100 \%$ & trunk injuries & $\begin{array}{l}\text { - damage from } 50 \% \text { to } 100 \% \text { of the perimeter of the trunk, } \\
\text { branches and root swellings }\end{array}$ \\
\hline
\end{tabular}

Biotic pests: a - fungi, b - insects, c - animals, d - human / (If type of damage represent type-a and if there is cavities on trunk, then evaluat the tree according to $\left(C f_{i}\right)$

\begin{tabular}{|c|c|c|c|}
\hline 0 & 0 & trunk cavities & - on the trunk there are no cavities or wood-destroying fungi \\
\hline 1 & $0-1 / 8 \cdot t d$ & trunk cavities & $\begin{array}{l}\text { - the existence of small cavities with a depth up to } 1 / 8 \text { of the } \\
\text { trunk diameter }\end{array}$ \\
\hline 2 & $1 / 8 \cdot t d-1 / 4 \cdot t d$ & trunk cavities & $\begin{array}{l}\text { - deeper cavities with a depth of } 1 / 8 \text { to } 1 / 4 \text { the trunk diameter, } \\
\text { with fungal sporangia }\end{array}$ \\
\hline 3 & $1 / 4 \cdot t d-1 / 2 \cdot t d$ & trunk cavities & $\begin{array}{l}\text { - deeper cavities with a depth of } 1 / 4 \text { to } 1 / 2 \text { the trunk diameter, } \\
\text { with fungal sporangia }\end{array}$ \\
\hline 4 & $1 / 2 \cdot t d$ - more & trunk cavities & $\begin{array}{l}\text { - deep cavities with a depth more than } 1 / 2 \text { of the trunk diameter, } \\
\text { with advanced mycelium }\end{array}$ \\
\hline 0 & $0 \cdot w$ & wound callus & $\begin{array}{l}\text { - there are no cavities or wound on the trunk, therefore callus } \\
\text { was not formed }\end{array}$ \\
\hline 1 & $1 / 8 \cdot w-1 / 4 \cdot w$ & wound callus & $\begin{array}{l}\text { - complete callus formation around the wound boundary more } \\
\text { than } 1 / 2 \text { of the wound area }\end{array}$ \\
\hline 2 & $1 / 4 \cdot w-1 / 3 \cdot w$ & wound callus & $\begin{array}{l}\text { - good callus formation around the wound boundary from } 1 / 3 \\
\text { to } 1 / 2 \text { of the wound area }\end{array}$ \\
\hline 3 & $1 / 3 \cdot w-1 / 2 \cdot w$ & wound callus & $\begin{array}{l}\text { - slight callus formation around the wound boundary from } 1 / 4 \\
\text { to } 1 / 3 \text { of the wound area }\end{array}$ \\
\hline 4 & $1 / 2 \cdot w-1 \cdot w$ & wound callus & $\begin{array}{l}\text { - low callus formation around the wound boundary from } 1 / 8 \\
\text { to } 1 / 4 \text { of the wound area }\end{array}$ \\
\hline
\end{tabular}

Source: Pejchal, 1995; Innes, 1990; Supuka et al., 1991; Hrubík a Tkáčová, 2004; Gáper, 1998; Gáper a Gáperová, 2009 $t d(\mathrm{~cm})$ - trunk diameter, $w\left(\mathrm{~cm}^{2}\right)$ - wound width, ok - trunk perimeter, $s$ - area of trunk or branch wounds 


\section{Results and discussion}

\section{Climate assessment of the reviewed period}

During the health assessment and measurement of chlorophyll- $\alpha$ fluorescence in Nitra there prevailed high maximum daily air temperatures, which in June reached $30.7^{\circ} \mathrm{C}$ in July and $36.8^{\circ} \mathrm{C}$, and in the month of August reached maximum daily air temperature up to $37.5{ }^{\circ} \mathrm{C}$. Monthly rainfall in this area did not exceed $10.2 \mathrm{~mm}$ in June, in July it was not more than $17.2 \mathrm{~mm}$ and in August there was $57.7 \mathrm{~mm}$ of rainfall. More detailed overview of climatic characteristics of the period is presented in Table 2.

Table 2 Climate characteristics - Nitra, 2015

\begin{tabular}{|l||c|c|c|c|}
\hline \multirow{2}{*}{ Month } & \multicolumn{3}{|c|}{ Air temperature } & Rainfall \\
\cline { 2 - 5 } & max & min & avg & sum \\
\hline \hline June & 30.7 & 7.9 & 19.9 & 10.2 \\
\hline July & 36.8 & 7.9 & 23.6 & 17.2 \\
\hline August & 37.5 & 10.0 & 23.5 & 57.7 \\
\hline & $\begin{array}{l}\text { Source: Author } \\
\text { max - maximum temperature, min - minimum } \\
\text { temperature, avg - average } \\
\text { sum - summary }\end{array}$ \\
\end{tabular}

During the health assessment and measurement of chlorophyll fluorescence in the park Nová Ves nad Žitavou there also prevailed high maximum daily temperatures, which in July reached $37.3^{\circ} \mathrm{C}$ in August to $36.9^{\circ} \mathrm{C}$ and in the month of September reached a maximum daily temperature of $35.8{ }^{\circ} \mathrm{C}$. Monthly rainfall was minimal in this area, in July it did not exceed $18.4 \mathrm{~mm}$, in August thanks to a few humid days it reached $165.8 \mathrm{~mm}$ and in September there were $61.2 \mathrm{~mm}$ of rainfall. More detailed overview of climate characteristics of this period is presented in Table 3.

Table 3 Climate characteristics - Nová Ves nad Žitavou, 2015

\begin{tabular}{|l||c|c|c|c|}
\hline \multirow{2}{*}{ Month } & \multicolumn{3}{c|}{ Air temperature } & Rainfall \\
\cline { 2 - 5 } & $\max$ & $\min$ & avg & sum \\
\hline \hline \multirow{2}{*}{ June } & 37.3 & 6.2 & 23.2 & 18.4 \\
\hline July & 36.9 & 10.9 & 22.7 & 165.8 \\
\hline August & 35.8 & 9.3 & 22.3 & 61.2 \\
\hline & $\begin{array}{l}\text { Source: Author } \\
\text { max - maximum temperature, min - minimum } \\
\text { temperature, avg - average } \\
\text { sum - summary }\end{array}$ \\
\end{tabular}

According to the monitoring program of the Slovak Hydrometeorological Institute in Bratislava and droughts in the Danube and the Eastern plains, this period in Nitra was characterized as extremely dry as can be seen in the graphic interpretation of temporal evolution of standardized rainfall index (SPI, Figure 1) and standardized rainfall and evapotranspiration index (SPEI, Figure 2).

SPI shows the relative deviation of rainfall during the period from long-term mean. Similarly, SPEI shows the

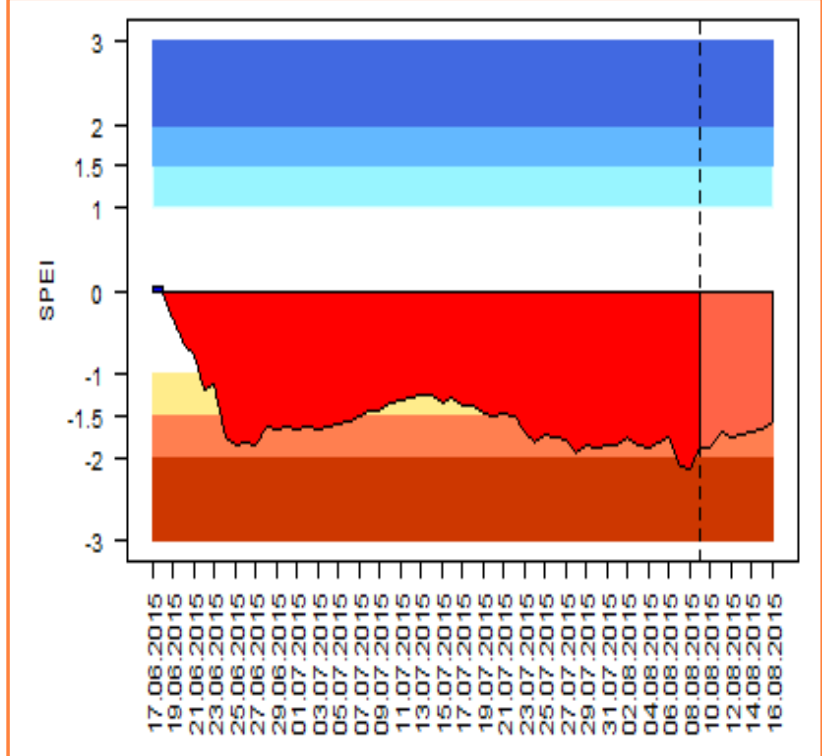

Figure 1 Parameter SPEI shape (development) in the period June - August 2015, Nitra

Source: Slovak Hydrometeorological Institute in Bratislava

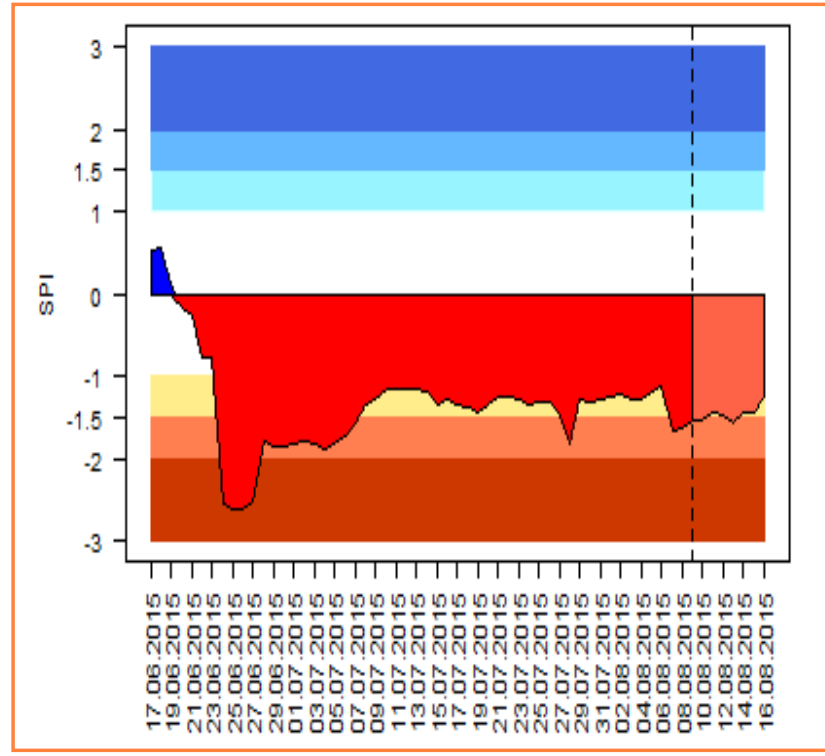

Figure 2 Parameter SPI shape (development) in the period June - August 2015, Nitra

Source: Slovak Hydrometeorological Institute in Bratislava

relative deviation from the long-term average value, but unlike SPI, which works only with rainfall, SPEI works with a simple water balance, rainfall - evapotranspiration. A negative index indicates dry conditions, and on the other hand, positive moisture conditions where the intensity was graded in each stage. The dry season begins with the decrease in the value -1 and ends when it reaches the values above 0 . Drought is identified by SPI. SPEI does not mean that the period in question was entirely without rainfall. Index shows that the deviations from the avarage value theoretical distribution of the measured values, and hence the deficit were not completely caused by the absence of rainfall. 
Both indexes have a 30-day cumulative time. This means that the index expressed for specific day determines a deviation of the rainfall, or water balance of specific day and the previous 29 days, which is applied to the "Sliding window" on the whole length of the data series (SHMU, 2015).

\section{The results of visual assessment}

The results of visual assessment of subjects grown in the area of Trieda A. Hlinku point to an obvious moderate defoliation $(D)$ and relatively strong crown dieback and crown mortification $(O k)$ for all three individuals and necrosis of leaves $(\mathrm{Ni})$ of $1^{\text {st }}$ grade in second and third subjects, and $2^{\text {nd }}$ grade for the first subject. Mechanical damage $(M p)$ is rated by higher value mainly for the first and second individual, because of presence of frost cracks and bark damage by unsuitable maintenance. Callus formating $(K)$ is in the first two subjects incomplete up to $1 / 8$ to $1 / 4$ of wound width. High value of the quality index $\left(Q_{1}\right), 9.33$ pointsis attributed to poor health of researched subjects. In the second term there is visibly deteriorated crown mortification and especially a higher rate of leaves necrosis, which are ultimately viewed in the deterioration of qualitative index $\left(Q_{1}\right)$ to 10.33 , what can be seen in Table 4.
In Table 5 we can see the results of the visual assessment of subjects in the park area in Nova Ves nad Žitavou, which are much higher when compared with the tested individuals in urban space. The final qualitative index $\left(Q_{2}\right)$ 2.66 is directly reflected in the high quality of assimilation organs $(\mathrm{Ni})$ and low loss of foliage $(\mathrm{D})$ especially in the first and third individual and moderately elevated markers such as defoliation, dieback of the crown and leaf necrosis (Ni). Mechanical damage $(\mathrm{Mp})$ was noted only in modest scale for the second and third individual because of frost cracks. The Callus formation $(K)$ was in the case of first and second subject from $1 / 2$ to complete wound width. When we compare the quality indexes of trees from the two localities, the individuals from the park demonstrate better quality values of assimilation organs and moderate impact of destructive manifestations especially in the crown mortification or trunk damage.

\section{Evaluation of chlorophyll- $\alpha$ fluorescence parameters}

Statistical values evaluation of the physiological parameter $\mathrm{Fv} / \mathrm{Fm}$ measured on subjects in two different localities refers to the high adaptability of subjects, or low environmental pressure in the park area of Nova Ves nad Žitavou compared to the location Trieda Andreja Hlinku in Nitra. Table 3 contains

Table 4 Visual trees evaluation in Nitra city

\begin{tabular}{|l||c|c|c|c|c|c|c|c|c|}
\hline Measurement & Subject & Latin name & $\mathbf{D}$ & $\mathbf{O k}$ & $\mathbf{N i}$ & $\mathbf{M p}$ & $\boldsymbol{V d}$ & $\boldsymbol{K}$ & $\mathbf{Q}$ \\
\hline 1. & 1 & Acerpseudoplatanus L. & 1 & 2 & 2 & 2 & 0 & 3 & 9.33 \\
\hline 1. & 2 & Acerpseudoplatanus L. & 2 & 2 & 1 & 3 & 0 & 3 & \\
\hline 1. & 3 & Acerpseudoplatanus L. & 1 & 2 & 1 & 1 & 0 & 0 & \\
\hline 2. & 1 & Acerpseudoplatanus L. & 1 & 2 & 3 & 2 & 0 & 3 & 10.33 \\
\hline 2. & 2 & Acerpseudoplatanus L. & 2 & 3 & 2 & 3 & 0 & 3 & \\
\hline 2. & 3 & Acerpseudoplatanus L. & 1 & 2 & 3 & 1 & 0 & 0 & \\
\hline
\end{tabular}

Source: Author

$\mathrm{D}$ - crown defoliation, $\mathrm{Ok}$ - dieback of the crown, $\mathrm{Ni}$ - necrosis of leaves, $\mathrm{Mp}$ - mechanical damage, $\mathrm{Vd}$ - incidence of cavities in the trunk or branches, $K$ - wounds callusing, $Q_{1}$ - qualitative index

Table 5 Visual trees evaluation in the park of Nová Ves nad Žitavou

\begin{tabular}{|l||c|c|c|c|c|c|c|c|c|}
\hline Measurement & Subject & Latin name & $\mathbf{D}$ & $\mathbf{O k}$ & $\mathbf{N i}$ & $\mathbf{M p}$ & $\boldsymbol{V d}$ & $\boldsymbol{K}$ & $\mathbf{Q}_{\mathbf{1}}$ \\
\hline \hline 1. & 1 & Acerpseudoplatanus L. & 0 & 0 & 0 & 0 & 0 & 1 & 2.66 \\
\hline 1. & 2 & Acerpseudoplatanus L. & 1 & 2 & 1 & 1 & 0 & 0 & \\
\hline 1. & 3 & Acerpseudoplatanus L. & 0 & 0 & 0 & 1 & 0 & 1 & 1 \\
\hline 2. & 1 & Acerpseudoplatanus L. & 0 & 0 & 0 & 0 & 0 & 2.66 \\
\hline 2. & 2 & Acerpseudoplatanus L. & 1 & 2 & 1 & 1 & 0 & 0 & 1 \\
\hline 2. & 3 & Acerpseudoplatanus L. & 1 & 0 & 0 & 1 & 0 & 1 \\
\hline
\end{tabular}

Source: Author

$\mathrm{D}$ - crown defoliation, $\mathrm{Ok}$ - dieback of the crown, $\mathrm{Ni}$ - necrosis of leaves, $\mathrm{Mp}$ - mechanical damage, $\mathrm{Vd}$ - incidence of cavities in the trunk or branches, $K$ - wounds callusing, $Q_{1}$ - qualitative index

Table 6 Parameter FV/Fm statistical evaluation measured at the two localities for two terms of measurement

\begin{tabular}{|l||c|c|c|c|c|c|}
\hline Locality & Avarage & Standart deviation & Variation coefficient & Minimum & Maximum & Range \\
\hline Nitra & 0.821 & 0.0222 & $2.7108 \%$ & 0.773 & 0.856 & 0.083 \\
\hline Park area & 0.832 & 0.0194 & $2.3374 \%$ & 0.783 & 0.867 & 0.084 \\
\hline
\end{tabular}

Source: Author 


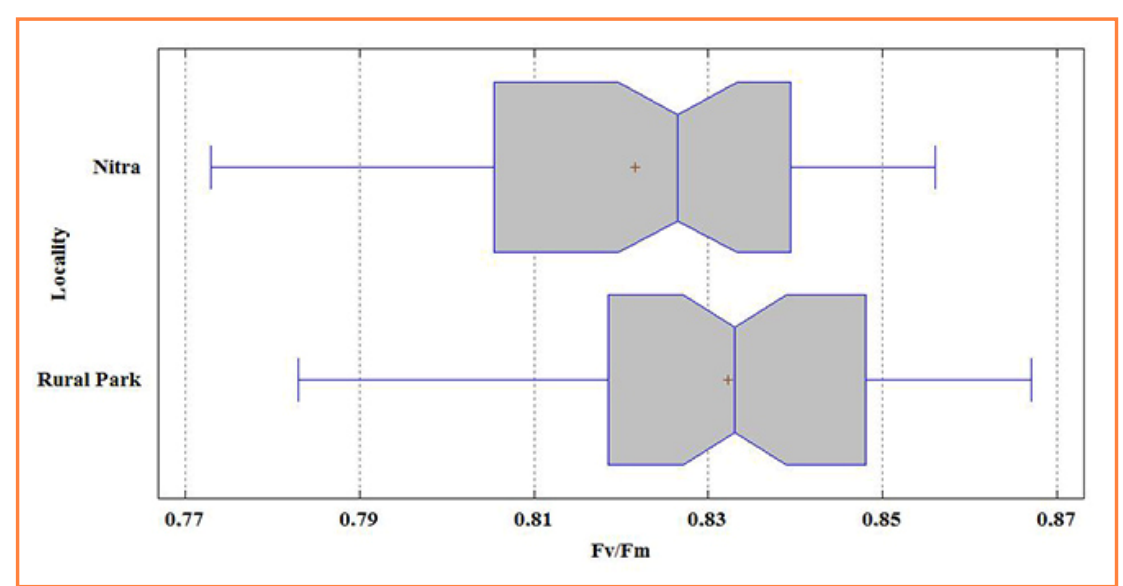

Figure 3 Median difference in statistical evaluation measured at the two localities for two terms of measurement in year 2015 Source: Author

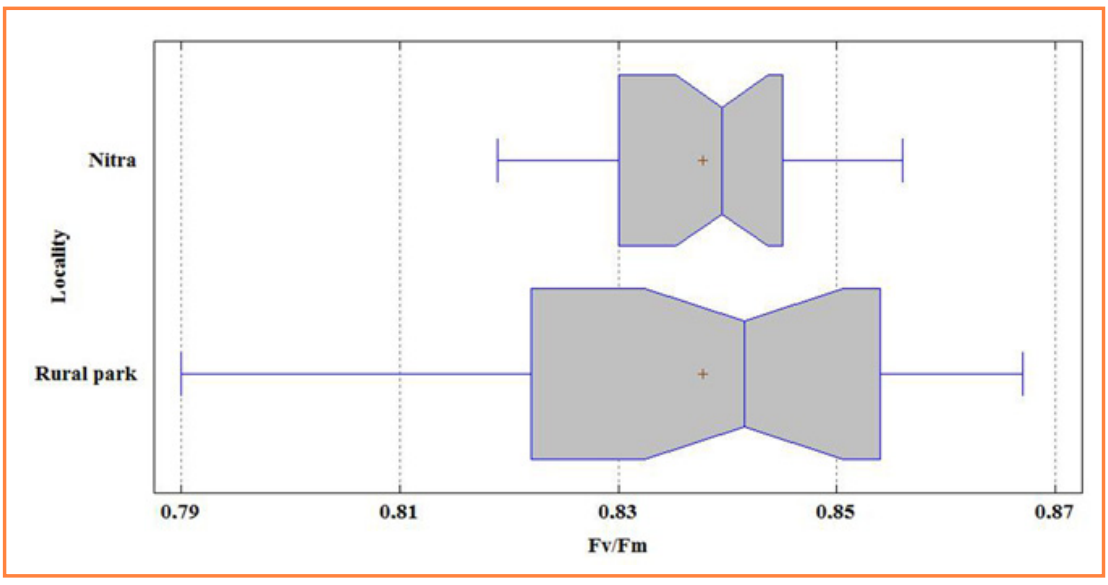

Figure 4 Parameter Fv/Fm medians difference measured at the two localities in the first term of measurement in year 2015 Source: Author

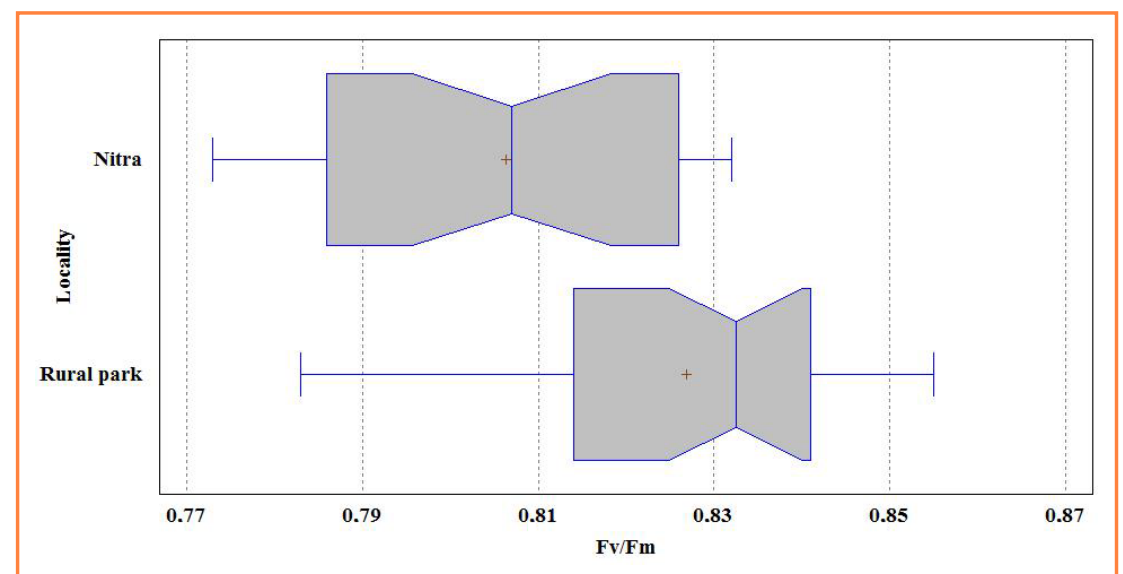

Figure 5 Parameter Fv/Fm Median difference measured at the two localities in the second term of measurement in the year 2015 Source: Author summary statistics of the measured physiological parameters for subjects measured in two locations where there is a significant difference in standard deviation, which reached the value 0.0194 in the park and 0.0222 in the urban area. Based on the statistical averages comparison (ANOVA test) of the observed physiological parameters $\mathrm{Fv} / \mathrm{Fm}$ there was found statistically highly significant difference in favour of subjects in the urban area where the $P$-value amounted to 0.0062 .

The result of Kruskal Wallis test showed that the $P$-value $=0.018$ and hence it is less than 0.05 and therefore represents statistically significant deviation among the median value of $\mathrm{Fv} / \mathrm{Fm}$ between the sites with a confidence level of $95.0 \%$.

On Figure 3 there is pictured a comparison of median values of $\mathrm{Fv} / \mathrm{Fm}$ during two measurements between the two localities. In the Figure 3 there can be seen the comparison of median values of $\mathrm{Fv} / \mathrm{Fm}$ during two measurements between the two sites. An avarage value in urban area reached 0.821 and it is visible in a wide variation of values, opposite what the median in the park area is demonstrably higher at 0.832 with a smaller range of values compared to the urban environment.

When we statistically evaluated the measured values of the parameters $\mathrm{Fv} / \mathrm{Fm}$ between individuals growing at the two locations only for the first period of measurement separately (Figure 4), then the statistically significant difference of medians is not statistically significant. The results of ANOVA test showed statistically insignificant difference with $P$-value $=$ 1.000 (Table 7).

Significant difference was reached mainly in the coefficient of variation, standard deviation, and the range of values which was measured in individuals in urban areas was significantly smaller. Based on the results of the climate data evaluation, we could expect that the parameter values have been affected by more

Table 7 Parameter Fv/Fm statistical evaluation measured at the two localities in the first term of measurement

\begin{tabular}{|l||c|c|c|c|c|c|}
\hline Locality & Avarage & Standart deviation & Variation coefficient & Minimum & Maximum & Range \\
\hline \hline Nitra & 0.836 & 0.0103 & $1.2381 \%$ & 0.819 & 0.856 & 0.037 \\
\hline Park area & 0.837 & 0.0195 & $2.3298 \%$ & 0.790 & 0.867 & 0.077 \\
\hline
\end{tabular}

Source: Author 
Table 8 Parameter Fv/Fm statistical evaluation measured at the two localities in the second term of measurement

\begin{tabular}{|l||c|c|c|c|c|c|}
\hline Locality & Avarage & Standart deviation & Variation coefficient & Minimum & Maximum & Range \\
\hline \hline Nitra & 0.806 & 0.0192 & $2.3823 \%$ & 0.773 & 0.832 & 0.059 \\
\hline Park area & 0.826 & 0.0180 & $2.1890 \%$ & 0.783 & 0.855 & 0.072 \\
\hline
\end{tabular}

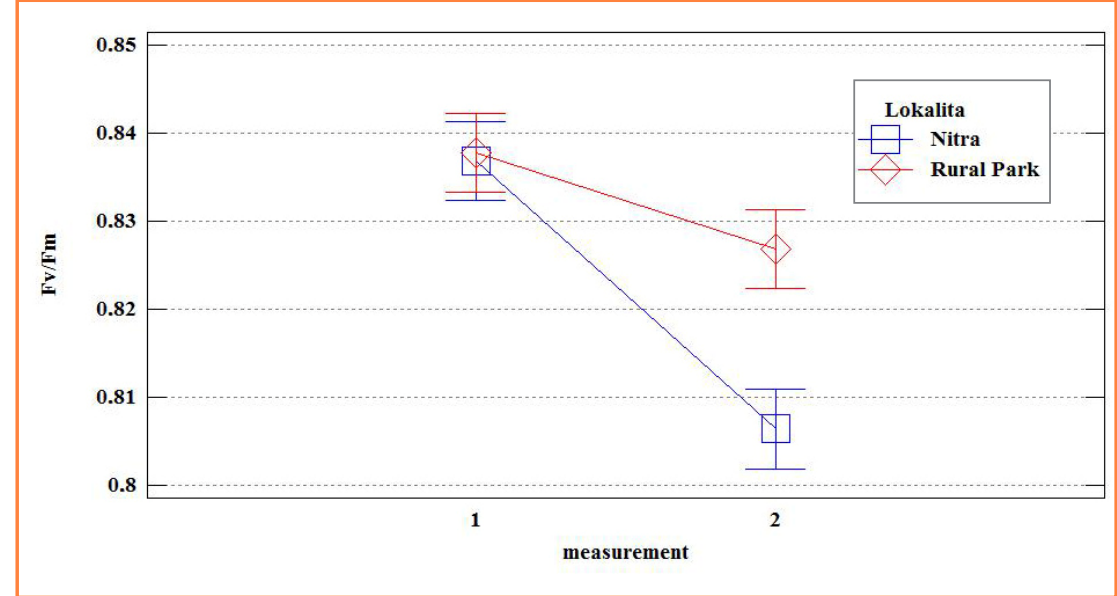

Figure 6 Parameter Fv/Fm Median difference of measured values at the two localities in the year 2015

Source: Author

1 - first measurement, 2. - second measurement

favourable and almost balanced air temperatures in urban areas during the first term of measurement.

Also, lingering rainfall soil water from the previous month could have increased the ability of the observed trees in urban areas to resist the incoming prolonged drought, or periods of high water deficiency and high maximum daily temperatures.

The results of ANOVA test between the locations for a second term of measurement showed highly significant deviation between the values of the medians with $P$-value $=$ 0.0001 , which represents a statistically highly significant difference with confidence level 95.0\%. There have been found higher values of standard deviation as well as variation dissipations (Table 8).

The compactness of the measured values during the second term of the measurement was better for the subjects in the park area (Figure 5). Median values were highly different for subjects in the park Nová Ves nad Žitavou and there were observed significantly higher values compared to those in the urban area. During the second measurements period thelimatic conditions of both sites changed. Air temperatures increased, which could have negative impact on the metabolic processes of assimilation tissue and consequently at the value of the parameter Fv/Fm just as expected.

In the evaluation of the observed parameters development with regard to the succession of measurements between the two locations (Figure 6), the results showed a distinct decrease in the values not only for the subjects in the park area but especially between the first and second term of measurements at the site in the urban area.

This could be a consequence of persistent droughts and rising daily temperatures which were higher in comparison with park places, which caused surfaces overheating which could lead to high water transpiration from the soil profile and the high leaf evaporating. The level of changed urban environment conditions significantly affects the vitality and health condition of trees, which is documented in results of measurements from other authors. The average value of the environmental load in Nitra-Chrenová 1 , and therefore at the location of our research have reached according to the measurement results from year 2012 by Rozová et al. (2013) the follows values: total dust $=0.060 \mathrm{mg} \mathrm{m}^{-3}$, $\mathrm{SO}_{2}=0.018 \mathrm{ppm}$, volatile organic compounds (VOC) - $0.037 \mathrm{ppm} \mathrm{CO}_{2}=$ $442.853 \mathrm{ppm}, \mathrm{CO}=2.299 \mathrm{ppm}, \mathrm{NO}_{\mathrm{x}}=$ $0.016 \mathrm{ppm}$. Although average values do not exceed hygienic limits, some of their short-term concentrations exceeded them especially during the summer time.

The research of authors who deal with the impacts of extreme temperatures at the plants as a stress factor for the their growth and development poinst to the fact that extreme air quality impacts reducing parameter Fv/Fm (Laposi et al., 2002).

As a consequence of extreme weather conditions in recent months it has caused early crown necrosis and early death of assimilation organs to evaluated individuals in urban areas. Similar results were recorded in research by Jasenka (2011). Two of the three assessed subjects of Acer pseudoplatanus L., were identical between our researches.

\section{Conclusion}

We evaluated six woody plants of species Acer pseudoplatanus L. on two types of localities. For urban area there was selected Trieda Andreja Hlinku street in Nitra, and for a park area the historical park in Nová Ves nad Žitavou. We conducted measurement on two dates. Specimens were evaluated visually by using of visual methodologies, and also by measurement of chlorophyll- $\alpha$ fluorescence parameters. The results of visual assessment showed different values between sites. The individuals in the park area had lower values of the quality index, $Q_{1}=2.66$ indicating a better quality of assimilation organs, less crown and trunk destructive characters compared to the evaluated trees in Nitra. They had the final value of the quality index $Q_{2}=9.33$ in the first period of evaluation and $Q_{2}=10.33$ in the second period of evaluation. The results of chlorophyll- $\alpha$ fluorescence measurement showed substantially lower quality of assimilation organs for subjects in the urban area, as it is shown on average value of the 
parameter Fv/Fm (0.821). In the park area of Nová Ves nad Žitavou there were measured higher values (0.832) than in the urban space. Provable differences were found in evaluation of average values between the two sites with regard to the measurement time. Greater reduction in values of $\mathrm{Fv} / \mathrm{Fm}$ parameter were statistically evaluated for the subjects in urban areas. The results of the evaluation showed a profound impact of worsened microclimatic conditions, environmental load by allochthonous substances and worse degree of adaptability trees at the site Trieda Andreja Hlinku Nitra.

\section{Acknowledgments}

This paper was elaborated with the financial support of the

\section{References}

grant project KEGA no. 003SPU-4 / 2014 $4^{\text {th }}$.

BERNATZKY, A. 1978. Ecology and Tree Preservation. Amsterdam, Oxford, New York : Elsevier, 1978, p. 83-86.

GÁPER, J. 1998. Tree fungus in Slovakia and dissemination of basidiospores ecosystems. Zvolen : TU, 1998. p. 5-75. ISBN 80-228-0750-8.

GÁPER, J. - GÁPEROVÁ, S. 2009. The cavities as an important part of the trees vitality assessment in settlements. In BERNADOVIČOVÁ, S. - JUHÁSOVÁ, G. (eds.): Plants in public green. Nitra : Institute of Forest Ecology, 2009. p.193-198

HRUBÍK, P. - TKÁČOVÁ, S. 2004. Inventory and classification of wood in Horticulture and Landscaping. In Collection of the International Conference: Settlement - Park - Landscape. Nitra : SUA, 2004, p. 87-89.

INNES, J. L. 1990. Assessment of tree condition. London : HMSO, 1990, $96 \mathrm{pp}$.

JASENKA, M. - SUPUKA, J. 2011. Evaluation of trees adaptability to the urban environment by the example of Sophora japonica L. In SALAS, P. (ed): Plants in conditions of changing climate. Fridge 20.21. 10. 2011, Úroda, 2011, p. 150-160. ISSN 0139-6013.

JASENKA, M. 2011. The influence of the urban environment on the biological processes of woody vegetation: Doctoral dissertation. Nitra : SUA, 2011. 137 pp.

KMEŤ, J. - DITMAROVÁ, L. - KURJAK, D. 2009. The physiological and biochemical parameters as potential bio-indicators of drought stress. Physiological and biomechanical parameters and potential drought indicators. In Acta Facultatis Forestalis, vol. 51, 2009, no. 3, pp. 67-76.

LAPOSI, R. et al. 2002. Photosynthetic ecophysiological properties of beech (Fagus sylvatica L.) under the exclusion of ambient UV-B radiation. In Acta Biologica Szegediensis, 2002, no. 46, pp. 243-245. LEUZINGER, S. - VOGT, R. - KÖRNER, C. 2010. Tree surface temperature in an urban environment. In Agricultural and Forest Meteorology, 2010, no. 150, pp. 56-62.

QUIGLEY, M, F. 2004. Street Trees and Rural conspecifics: Will Long-lived Trees Reach Full. Size in Urban Conditions. In Urban Ecosystems, 2004, no. 7, pp. 29-39.

PEJCHAL, M. 1995. Evaluation of trees vitality in urban streets. In Collective (eds): The trees in the streets. Olomouc - Mělník: Section Care of trees at the Society for Landscape and Garden, 1994. pp. 32-40.

PEJCHAL, M. 1997. Evaluation of tree vitality. In City Park, Nitra : SUA, 1997, pp. p. 9-32.

ROZOVÁ, Z. et al. 2013. Environmental aspects of the urban environment. Nitra : UKF, 2013. 390 pp. ISBN 978-80-558-0388-3.

SHMU. 2015. Available at urlURL: http://www.shmu.sk/ sk/?page $=2049 \& i d=595$

SLOVÁKOVÁ, L. - MISTRÍK, I. - 2007. The physiological processes of plants under stress. Bratislava : Comenius University, 2007, pp. 232. ISBN 978-80-223-2322-2.

STŘELCOVÁ, K. - KMET, J. 2003. Physiological aspects of dry forests. In Les, vol. 59, 2003, no. 9, pp. 8-10.

SUPUKA, J. et al. 1991. Ecological principles of creation and green protection. Bratislava : VEDA, Slovak Academy of Sciences Publishing, 1991. $308 \mathrm{p}$.

SUPUKA, J. - KMEŤ, J. - JASENKA, J. 2010. Selected parameters of chlorophyll- $\alpha$ fluorescence in the plants leaves in urban conditions. In Acta Horticulturae et Regitecturae, vol. 13, 2010, special issue, pp. 1-7. ISSN 1335-2563. 